\title{
Understanding the role of active site residues in CotB2 catalysis using a cluster model
}

\author{
Keren Raz ${ }^{1}$, Ronja Driller ${ }^{2,3,4}$, Thomas Brück ${ }^{5}$, Bernhard Loll ${ }^{2}$ and Dan T. Major ${ }^{* 1}$
}

\section{Full Research Paper}

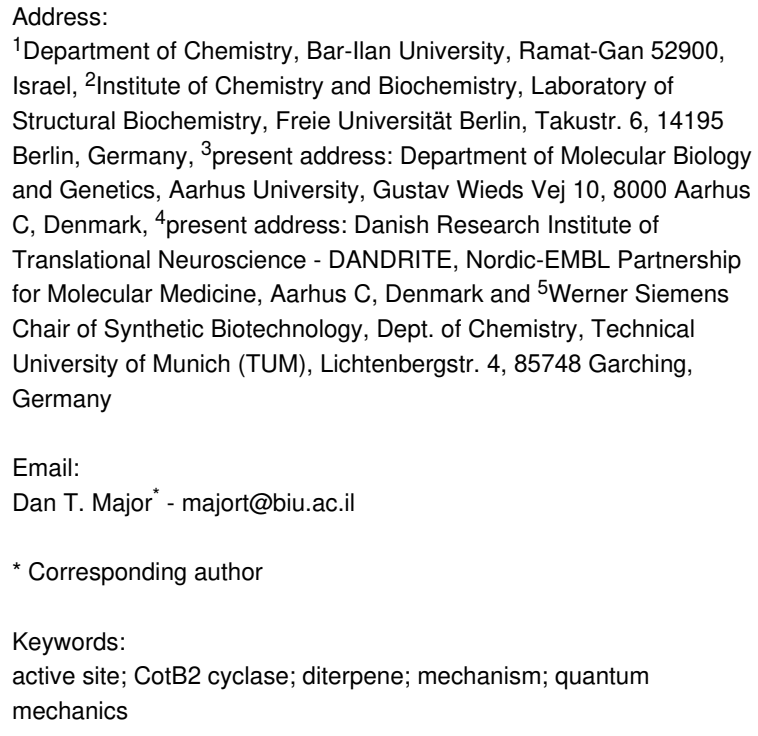

Beilstein J. Org. Chem. 2020, 16, 50-59.

doi:10.3762/bjoc. 16.7

Received: 25 September 2019

Accepted: 17 December 2019

Published: 08 January 2020

This article is part of the thematic issue "Reactive intermediates carbocations".

Guest Editor: S. R. Hare

(C) 2020 Raz et al.; licensee Beilstein-Institut.

License and terms: see end of document.

\begin{abstract}
Terpene cyclases are responsible for the initial cyclization cascade in the multistep synthesis of a large number of terpenes. CotB2 is a diterpene cyclase from Streptomyces melanosporofaciens, which catalyzes the formation of cycloocta-9-en-7-ol, a precursor to the next-generation anti-inflammatory drug cyclooctatin. In this work, we present evidence for the significant role of the active site's residues in CotB2 on the reaction energetics using quantum mechanical calculations in an active site cluster model. The results revealed the significant effect of the active site residues on the relative electronic energy of the intermediates and transition state structures with respect to gas phase data. A detailed understanding of the role of the enzyme environment on the CotB2 reaction cascade can provide important information towards a biosynthetic strategy for cyclooctatin and the biomanufacturing of related terpene structures.
\end{abstract}

\section{Introduction}

Enzymes catalyze numerous complex biochemical reactions in different cellular compartments $[1,2]$. More specifically, the enigmatic class of terpene cyclases is responsible for converting linear aliphatic oligoprenyl diphosphates into various chemically complex macrocyclic products. The resulting terpene scaffolds and their functionalized terpenoid analogues comprise the 
largest and structurally most diverse family of natural products, currently representing over 80,000 reported structures from all kingdoms of life [3]. The largest diversity of terpenoids is reported for the plant kingdom where higher terpenes represent secondary metabolic products, which are responsible for, e.g., defense against biotic and abiotic stress or for attracting insects for pollination [4,5]. Industrially, terpene natural products are employed as flavoring agents [6], fragrances, pigments, cosmetics, perfumes, biofuels, and agrochemicals [5]. Additionally, terpene natural products with numerous pharmacological $[7,8]$ and biological activities have been reported, rendering them important targets for medical and biotechnology research [9]. Chemical synthetic and sustainable biosynthetic strategies in synergy with the biological activity of different terpene natural products have been reviewed elsewhere [3,10-17].

The first crystal structure of a monoterpene cyclase [18] was reported in 2002. Subsequently, the first crystal structures of a sesquiterpene $[19,20]$ and a triterpene [21] cyclase were published in 1997. Less than a decade ago, the first crystal structure of a diterpene cyclase was reported by Christianson and co-workers [22]. These structures, in conjunction with extensive biochemical work $[10,13,14,23]$, have contributed to the understanding of mechanistic details of terpene cyclases and facilitated rational enzyme design [24]. Theoretical quantum mechanical (QM) investigations on the chemistry of terpenes in the gas phase have provided a detailed understanding of the carbocation mechanisms underlying terpene synthase function [25-27]. Further, we have used multiscale modeling tools to study the effects of the enzyme environment in catalyzing reactions of mono-, sesqui-, and diterpene synthases [28-36].

Diterpenes are generated from the universal aliphatic substrate geranyl geranyl pyrophosphate (GGPP) [4]. In vitro experiments demonstrated that many diterpenes have pharmaceutical applications by featuring anticancer, antibacterial, anti-inflammatory, and antiretroviral activities [37]. Moreover, they are applied in the food industry as antioxidants and sweeteners [4].

CotB2 is a bacterial diterpene cyclase from $S$. melanosporofaciens, which catalyzes the formation of cyclooctat-9-en-7-ol, representing the first committed step in the biosynthesis of the next-generation anti-inflammatory drug cyclooctatin. The intracellular target of cyclooctatin is an as of yet uncharacterized lysophospholipase, which is involved in early steps of the inflammatory signaling cascade [38-40]. In the last decade, numerous interdisciplinary studies have addressed the chemical mechanism of CotB2 catalysis utilizing different detection and analysis methods.

Meguro and co-workers [41] established the chemical mechanism for the formation of cyclooctatin using isotope labeling experiments (Scheme 1). Recently, Hong and Tantillo [38] and Sato and co-workers [39] investigated the CotB2 mechanism using QM tools. According to Meguro and co-workers [41], the cyclization process commences with the dissociation of the pyrophosphate leaving group of GGPP, forming an allylic carbocation, and two subsequent electrophilic cyclizations to

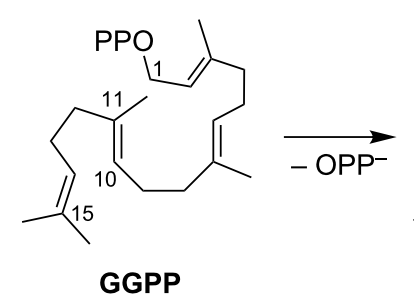

GGPP
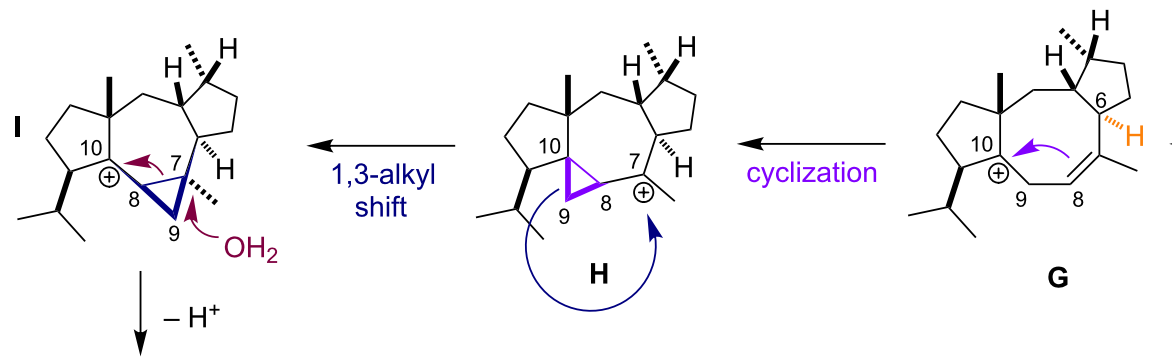

G
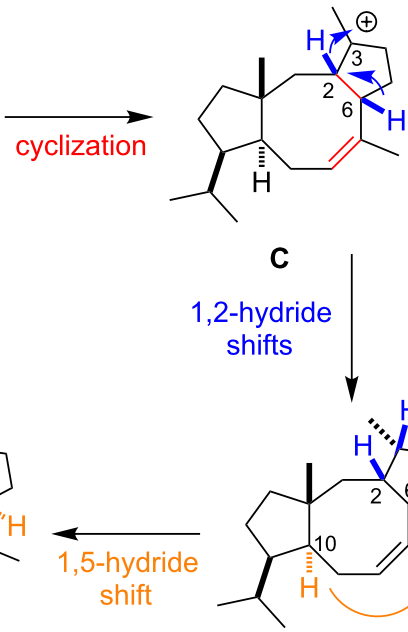

C
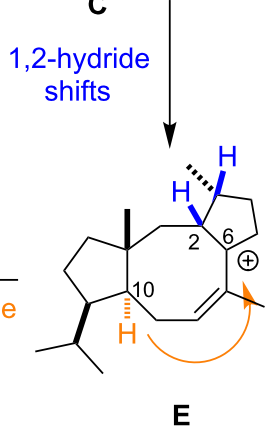

cycloocta-9-en-7-ol 
generate intermediate A. Intermediate $\mathbf{A}$ undergoes a 1,5hydride shift, forming intermediate B. A subsequent cyclization forms intermediate $\mathbf{C}$. Intermediate $\mathbf{C}$ generates intermediate $\mathbf{E}$ via one of two possible pathways: either a direct 1,3hydride shift or an indirect pathway involving two 1,2-hydride shifts. Theoretical investigations by Hong and Tantillo suggested that the indirect transformation from intermediate $\mathbf{C}$ to $\mathbf{E}$ is energetically favored and might be biosynthetically relevant [38]. This finding is in agreement with the report by Sato and co-workers [39], who performed isotope labeling experiments combined with QM calculations. Intermediate $\mathbf{G}$ forms via a 1,5-hydride shift from C6 to C10 to generate a homoallylic cation, and the formation of intermediate $\mathbf{H}$ occurs due to cyclization to yield a cyclopropyl ring. Intermediate $\mathbf{I}$ forms due to isomeric formation of a cyclopropylcarbinyl cation, as shown by isotope labeling [41]. QM calculations support this unusual 1,3-alkyl shift that interconverts $\mathbf{H}$ and $\mathbf{I}[38,39]$. Finally, the cyclopropyl ring opens by virtue of a nucleophilic water attack, and cyclooctat-9-en-7-ol is formed.

Although gas phase calculations shed light on the reactivity of the isolated species and provided crucial mechanistic insights, the biorelevant mechanism cannot be fully understood without taking into account the enzyme-solvent environment. A common problem when studying these enzymes is the lack of high-resolution crystal structures that are biologically relevant, i.e., that have a ligand bound in a reactive configuration and have a fully closed active site. Recently, a crystal structure of the CotB2 enzyme that met these criteria was published [42]. In the current work, we describe the crucial role of the amino acids in the active site on the reaction energetics using QM calculations in an active site cluster model. The active site cluster theozyme model $[43,44]$ was constructed from the crystal structure coordinates of active site amino acids, which were presumed to stabilize the carbocations during the reaction cascade. Each reaction step's relevant species was optimized in the active site model within a fixed enzyme approximation. The results obtained using the active site model were compared with gas phase data.

\section{Results and Discussion}

The energy profiles for both gas phase (orange) and for the active site model (blue) reactions were characterized by a sequential decreasing pattern (Figure 1). The inspection of the

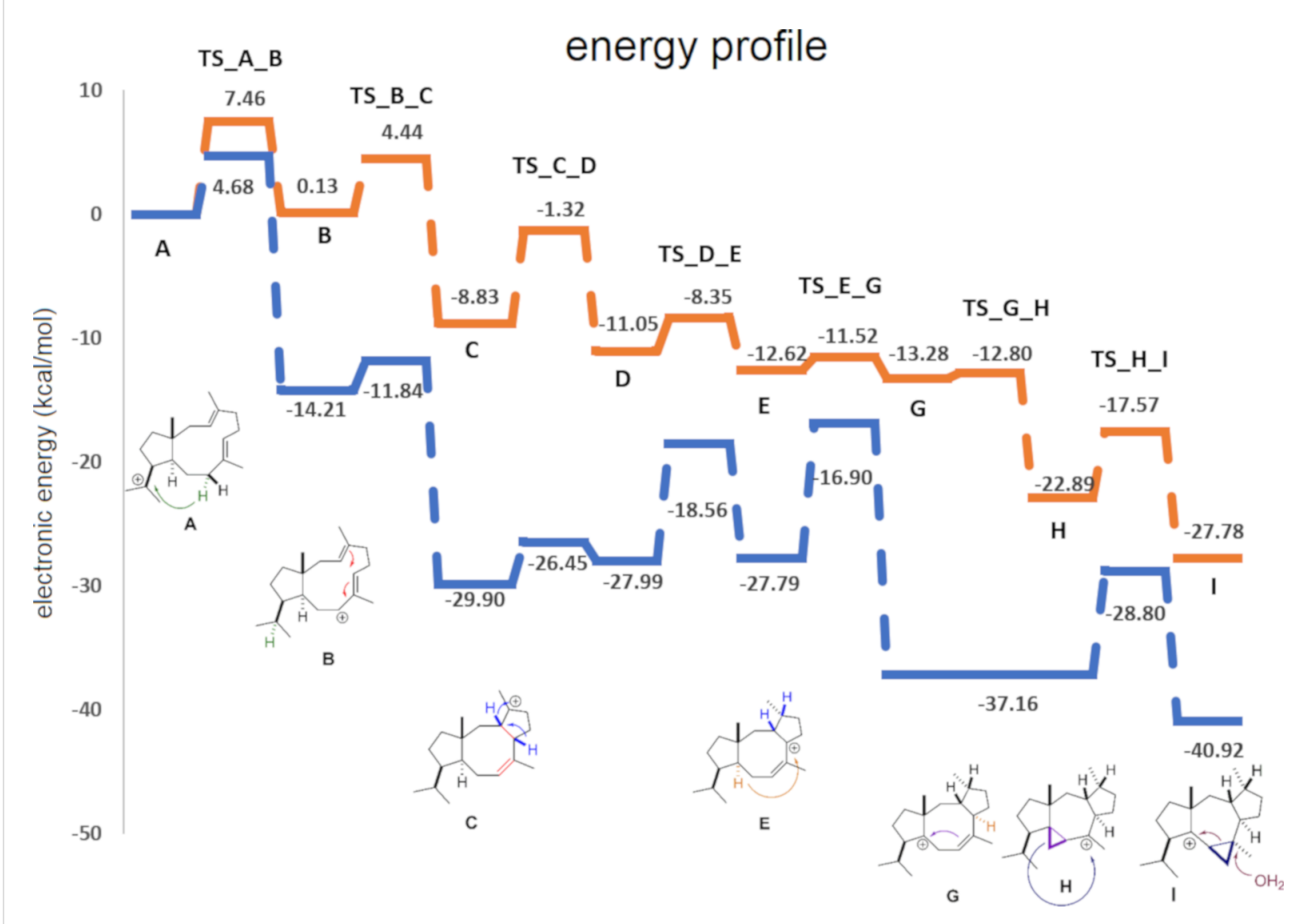

Figure 1: Computed electronic energy profiles $(\mathrm{kcal} / \mathrm{mol})$ for the CotB2 cyclase mechanism. The calculations used M062X/6-31+G(d,p). 
gas phase profile revealed important information regarding the inherent reactivity [27] of the carbocation species. As the reaction proceeded, $\pi$-bonds transformed into $\sigma$-bonds, explaining the steady downhill progress of the energy profile. An additional feature was the relatively low energy barrier of less than ca. $10 \mathrm{kcal} / \mathrm{mol}$ separating the intermediates. The gas phase mechanism has been discussed extensively by Hong and
Tantillo [38] and Sato and co-workers [39]. Herein, we focused on the differences between gas phase and active site model energies. All interaction distances are provided in Table 1, which provided the basis for the following categorization of interactions as $\pi$-cation, dipole-cation, and charge-cation. Note, that no attempts to quantify the individual pairwise interactions were made.

\begin{tabular}{|c|c|c|c|c|}
\hline \multirow{3}{*}{$\begin{array}{l}\text { intermediate } \\
\text { A }\end{array}$} & \multicolumn{2}{|c|}{ interacting species } & \multirow{3}{*}{$\begin{array}{l}\text { distance }(\AA) \\
4.49 \\
3.80\end{array}$} & \multirow{3}{*}{$\begin{array}{l}\text { interaction type } \\
\text { п-cation } \\
\text { dipole-cation }\end{array}$} \\
\hline & W186 & $\mathrm{C}_{15}$ & & \\
\hline & $\mid 181$ & $\mathrm{C}_{15}$ & & \\
\hline \multirow[t]{12}{*}{ B } & N103 & $\mathrm{C}_{6}$ & 4.66 & dipole-cation $(\mathrm{C}=\mathrm{O})$ \\
\hline & N103 & $\mathrm{C}_{7}$ & 4.72 & dipole-cation $(\mathrm{C}=\mathrm{O})$ \\
\hline & N103 & $\mathrm{C}_{8}$ & 4.41 & dipole-cation $(\mathrm{C}=\mathrm{O})$ \\
\hline & T106 & $\mathrm{C}_{6}$ & 3.96 & dipole-cation $(\mathrm{OH})$ \\
\hline & T106 & $\mathrm{C}_{7}$ & 4.15 & dipole-cation $(\mathrm{OH})$ \\
\hline & T106 & $\mathrm{C}_{8}$ & 5.33 & dipole-cation $(\mathrm{OH})$ \\
\hline & $\mathrm{F} 107$ & $\mathrm{C}_{6}$ & 4.25 & п-cation \\
\hline & $\mathrm{F} 107$ & $\mathrm{C}_{7}$ & 5.53 & п-cation \\
\hline & F107 & $\mathrm{C}_{8}$ & 5.88 & п-cation \\
\hline & $\mid 181$ & $\mathrm{C}_{6}$ & 5.15 & dipole-cation \\
\hline & I181 & $\mathrm{C}_{7}$ & 4.45 & dipole-cation \\
\hline & I181 & $\mathrm{C}_{8}$ & 4.14 & dipole-cation \\
\hline \multirow[t]{3}{*}{ C } & $\mathrm{O}_{3}$ & $\mathrm{C}_{3}$ & 4.20 & anion-cation \\
\hline & F107 & $\mathrm{C}_{3}$ & 3.65 & п-cation \\
\hline & $\mid 181$ & $\mathrm{C}_{3}$ & 4.72 & dipole-cation \\
\hline \multirow[t]{2}{*}{ D } & $\mathrm{O}_{3}$ & $\mathrm{C}_{2}$ & 5.03 & anion-cation \\
\hline & F107 & $\mathrm{C}_{2}$ & 4.35 & п-cation \\
\hline \multirow[t]{12}{*}{ E } & N103 & $\mathrm{C}_{6}$ & 4.74 & dipole-cation $(\mathrm{C}=\mathrm{O})$ \\
\hline & N103 & $\mathrm{C}_{7}$ & 3.81 & dipole-cation $(\mathrm{C}=\mathrm{O})$ \\
\hline & N103 & $\mathrm{C}_{8}$ & 3.04 & dipole-cation $(\mathrm{C}=\mathrm{O})$ \\
\hline & T106 & $\mathrm{C}_{6}$ & 4.43 & dipole-cation $(\mathrm{OH})$ \\
\hline & T106 & $\mathrm{C}_{7}$ & 4.25 & dipole-cation $(\mathrm{OH})$ \\
\hline & T106 & $\mathrm{C}_{8}$ & 5.32 & dipole-cation $(\mathrm{OH})$ \\
\hline & F107 & $\mathrm{C}_{6}$ & 4.66 & п-cation \\
\hline & $\mathrm{F} 107$ & $\mathrm{C}_{7}$ & 5.37 & п-cation \\
\hline & F107 & $\mathrm{C}_{8}$ & 5.54 & п-cation \\
\hline & $\mathrm{F} 149$ & $\mathrm{C}_{6}$ & 5.84 & п-cation \\
\hline & $\mathrm{F} 149$ & $\mathrm{C}_{7}$ & 6.42 & ח-cation \\
\hline & $\mathrm{F} 149$ & $\mathrm{C}_{8}$ & 7.75 & п-cation \\
\hline \multirow[t]{5}{*}{$\mathbf{G} / \mathbf{H}$} & N103 & $\mathrm{C}_{7}$ & 5.91 & dipole-cation \\
\hline & T106 & $\mathrm{C}_{7}$ & 5.27 & dipole-cation $(\mathrm{OH})$ \\
\hline & $\mathrm{F} 149$ & $\mathrm{C}_{7}$ & 5.35 & п-cation \\
\hline & $\mid 181$ & $\mathrm{C}_{7}$ & 3.08 & dipole-cation $(\mathrm{C}=\mathrm{O})$ \\
\hline & W186 & $\mathrm{C}_{7}$ & 6.48 & п-cation \\
\hline \multirow[t]{3}{*}{ I } & N103 & $\mathrm{C}_{10}$ & 5.44 & dipole-cation \\
\hline & $\mid 181$ & $\mathrm{C}_{10}$ & 3.31 & dipole-cation $(\mathrm{C}=\mathrm{O})$ \\
\hline & W186 & $\mathrm{C}_{10}$ & 5.87 & п-cation \\
\hline
\end{tabular}




\begin{tabular}{|c|c|c|c|c|}
\hline TS structure & \multicolumn{2}{|c|}{ interaction species } & distance $\AA$ & interaction type \\
\hline \multirow[t]{4}{*}{ A_B } & $\mid 181$ & $\mathrm{C}_{15}$ & 3.85 & dipole-cation \\
\hline & $\mid 181$ & $\mathrm{C}_{8}$ & 4.80 & dipole-cation \\
\hline & W186 & $\mathrm{C}_{15}$ & 4.48 & ח-cation \\
\hline & W186 & $\mathrm{C}_{8}$ & 5.09 & п-cation \\
\hline \multirow[t]{10}{*}{ B_C } & $\mathrm{O}_{3}$ & $\mathrm{C}_{2}$ & 3.78 & \\
\hline & $\mathrm{O}_{3}$ & $\mathrm{C}_{6}$ & 5.88 & anion-cation \\
\hline & N103 & $\mathrm{C}_{2}$ & 6.26 & \\
\hline & N103 & $\mathrm{C}_{6}$ & 4.80 & dipole-cation $(\mathrm{C}=\mathrm{O})$ \\
\hline & T106 & $\mathrm{C}_{2}$ & 6.80 & \\
\hline & T106 & $\mathrm{C}_{6}$ & 4.30 & dipole-cation $(\mathrm{OH})$ \\
\hline & F107 & $\mathrm{C}_{2}$ & 4.12 & \\
\hline & F107 & $\mathrm{C}_{6}$ & 4.36 & п-cation \\
\hline & $\mid 181$ & $\mathrm{C}_{2}$ & 4.33 & \\
\hline & I181 & $\mathrm{C}_{6}$ & 4.80 & dipole-cation \\
\hline \multirow[t]{6}{*}{ C_D } & $\mathrm{O}_{3}$ & $\mathrm{C}_{2}$ & 4.88 & anion-cation \\
\hline & $\mathrm{O}_{3}$ & $\mathrm{C}_{3}$ & 4.39 & anion-cation \\
\hline & F107 & $\mathrm{C}_{2}$ & 4.42 & п-cation \\
\hline & F107 & $\mathrm{C}_{3}$ & 3.61 & п-cation \\
\hline & $\mid 181$ & $\mathrm{C}_{2}$ & 4.00 & dipole-cation \\
\hline & I181 & $\mathrm{C}_{3}$ & 4.85 & dipole-cation \\
\hline \multirow[t]{6}{*}{ D_E } & $\mathrm{O}_{3}$ & $\mathrm{C}_{2}$ & 4.66 & anion-cation \\
\hline & $\mathrm{O}_{3}$ & $\mathrm{C}_{6}$ & 5.82 & anion-cation \\
\hline & F107 & $\mathrm{C}_{2}$ & 4.55 & п-cation \\
\hline & F107 & $\mathrm{C}_{6}$ & 5.37 & п-cation \\
\hline & F149 & $\mathrm{C}_{2}$ & 5.93 & п-cation \\
\hline & $\mathrm{F} 149$ & $\mathrm{C}_{6}$ & 5.05 & п-cation \\
\hline \multirow[t]{7}{*}{ E_G/H } & N103 & $\mathrm{C}_{6}$ & 6.09 & dipole-cation $(\mathrm{C}=\mathrm{O})$ \\
\hline & N103 & $\mathrm{C}_{10}$ & 5.20 & dipole-cation $(\mathrm{C}=\mathrm{O})$ \\
\hline & F107 & $\mathrm{C}_{6}$ & 5.07 & п-cation \\
\hline & F107 & $\mathrm{C}_{10}$ & 5.15 & п-cation \\
\hline & $\mathrm{F} 149$ & $\mathrm{C}_{6}$ & 5.42 & п-cation \\
\hline & $\mid 181$ & $\mathrm{C}_{6}$ & 3.62 & dipole-cation $(\mathrm{OH})$ \\
\hline & $\mid 181$ & $\mathrm{C}_{10}$ & 3.84 & dipole-cation $(\mathrm{OH})$ \\
\hline \multirow[t]{10}{*}{ G/H_I } & N103 & $\mathrm{C}_{7}$ & 5.41 & dipole-cation \\
\hline & N103 & $\mathrm{C}_{10}$ & 5.81 & dipole-cation \\
\hline & T106 & $\mathrm{C}_{7}$ & 5.11 & dipole-cation $(\mathrm{OH})$ \\
\hline & T106 & $\mathrm{C}_{10}$ & 7.29 & dipole-cation $(\mathrm{OH})$ \\
\hline & F149 & $\mathrm{C}_{7}$ & 5.68 & п-cation \\
\hline & F149 & $\mathrm{C}_{10}$ & 7.76 & п-cation \\
\hline & $\mid 181$ & $\mathrm{C}_{7}$ & 3.47 & dipole-cation $(\mathrm{C}=\mathrm{O})$ \\
\hline & $\mid 181$ & $\mathrm{C}_{10}$ & 3.03 & dipole-cation $(\mathrm{C}=\mathrm{O})$ \\
\hline & W186 & $\mathrm{C}_{7}$ & 6.09 & п-cation \\
\hline & W186 & $\mathrm{C}_{10}$ & 5.70 & п-cation \\
\hline
\end{tabular}

Carbocation A was stabilized through $\pi$-cation interaction with W186, while $\mathbf{B}$ was stabilized due to dipole-cation interactions of the allylic carbocation at C6-C7-C8 with N103, T106, and
I181. These variations in interactions resulted in an energy difference of $14.2 \mathrm{kcal} / \mathrm{mol}$, favoring $\mathbf{B}$, and the barrier was reduced by $2.8 \mathrm{kcal} / \mathrm{mol}$ (Figure 1 ). Another possible reason for 
the stabilization was that $\mathrm{C} 7$ had a greater proximity to the pyrophosphate group than C15 (6.71 ̊ vs $7.54 \AA$, Table 1 and Figure 2). The energy difference between $\mathbf{B}$ and $\mathbf{C}$ was $15.7 \mathrm{kcal} / \mathrm{mol}$ in the active site model, compared to $8.7 \mathrm{kcal} / \mathrm{mol}$ in the gas phase. Here, the energy gain was likely due to the fact that the carbocation in intermediate $\mathbf{C}$ was located $4.21 \AA$ away from the pyrophosphate group, which stabilized it (Table 1 and Figure 2). Moreover, $\pi$-cation interactions with F107 contributed to the stabilization as well. The activation energy for the formation of $\mathbf{C}$ was $2.4 \mathrm{kcal} / \mathrm{mol}$ in the active site model compared to $4.3 \mathrm{kcal} / \mathrm{mol}$ in the gas phase. In the active site model, D was less stable than $\mathbf{C}$ by almost $2 \mathrm{kcal} / \mathrm{mol}$, while in the gas phase, $\mathbf{D}$ was more stable by ca. $2 \mathrm{kcal} / \mathrm{mol}$. The main reason for this difference was possibly a difference in the conformation of $\mathbf{D}$ in the active site model compared to the gas phase. The dihedral angle defined by C3-C2-C6-C7 in $\mathbf{D}$ was greater by $53^{\circ}$ in the active site model than in the gas phase, and the $\mathbf{D}$ dihedral angle $\mathrm{C} 10-\mathrm{C} 9-\mathrm{C} 8-\mathrm{C} 7$ in the active site was smaller by $258^{\circ}$ than in the gas phase (Figure $4 \mathrm{a}$ ). Moreover, the dihedral angle $\mathrm{C} 2-\mathrm{C} 1-\mathrm{C} 11-\mathrm{C} 10$ was greater by $281^{\circ}$ in the active site model. The distance between $\mathrm{C} 4$ and $\mathrm{C} 13$ was significantly greater in the active site model $(1.2 \AA)$, indicating a more extended conformation. Figure 4a shows clearly that intermediate D was more folded in the gas phase than in the active site model. The required activation energy to form $\mathbf{D}$ was $4.1 \mathrm{kcal} / \mathrm{mol}$ lower in the active site model than the gas phase, likely due to $\pi$-cation interactions with F107 and F149 and greater proximity to the negatively charged pyrophosphate group. Another conformational difference between the gas phase and in the enzyme model was noted for $\mathbf{E}$ as well (Figure $4 \mathrm{~b}$ ). The dihedral angle $\mathrm{C} 2-\mathrm{C} 3-\mathrm{C} 4-\mathrm{C} 5$ was greater by $285^{\circ}$, and C10-C9-C $8-\mathrm{C} 7$ was smaller by $294^{\circ}$ in the active site model than in the gas phase. Moreover, the angle $\mathrm{C} 2-\mathrm{C} 1-\mathrm{C} 11$ was greater by $5^{\circ}$ in the active site model than in the gas phase, and the distance between $\mathrm{C} 4$ and $\mathrm{C} 13$ was smaller by $0.5 \AA$ in the gas phase. The net result of these differences was that intermediate $\mathbf{E}$ was more folded in the gas phase, although it was not as dramatically folded as $\mathbf{D}$. The reason for greater folding in the gas phase could have been a tendency to adopt conformations that maximized intramolecular dispersion interactions $[45,46]$. In the active site model of $\mathbf{E}$, the carbocation at C6 had a greater distance from the pyrophosphate group than $\mathrm{C} 2$ in cation $\mathbf{D}(6.03 \AA$ vs $5.03 \AA$ ) and likely contributed to a slight destabilizing effect in the active site model. This was in spite of interactions between cation D and N103, T106, F107, and F149. Nonetheless, the energy barrier to form $\mathbf{E}$ was higher in the active site model than in the gas phase. An elevated energy barrier was also observed for the formation of $\mathbf{G}$ (by almost $10 \mathrm{kcal} / \mathrm{mol}$ ). This may be explained by the loss of interactions between $\mathbf{G}$ and the pyrophosphate moiety as the cation moved further away, deeper into the hydrophobic part of the pocket. A distinct carbocation $\mathbf{G}$ was not observed in the enzyme model. Instead, a cation resembling $\mathbf{H}$, with a $\mathrm{C} 8-\mathrm{C} 10$ bond that was already partly formed, was observed. This carbocation was more stable in the active site model than $\mathbf{G}$ in the gas phase by almost $9 \mathrm{kcal} / \mathrm{mol}$. Hence, in the enzyme model, cation $\mathbf{G}$ was not a stable species, and instead, $\mathbf{H}$ was formed spontaneously. The energy for the transformation of $\mathbf{E}$ to $\mathbf{H}$ was

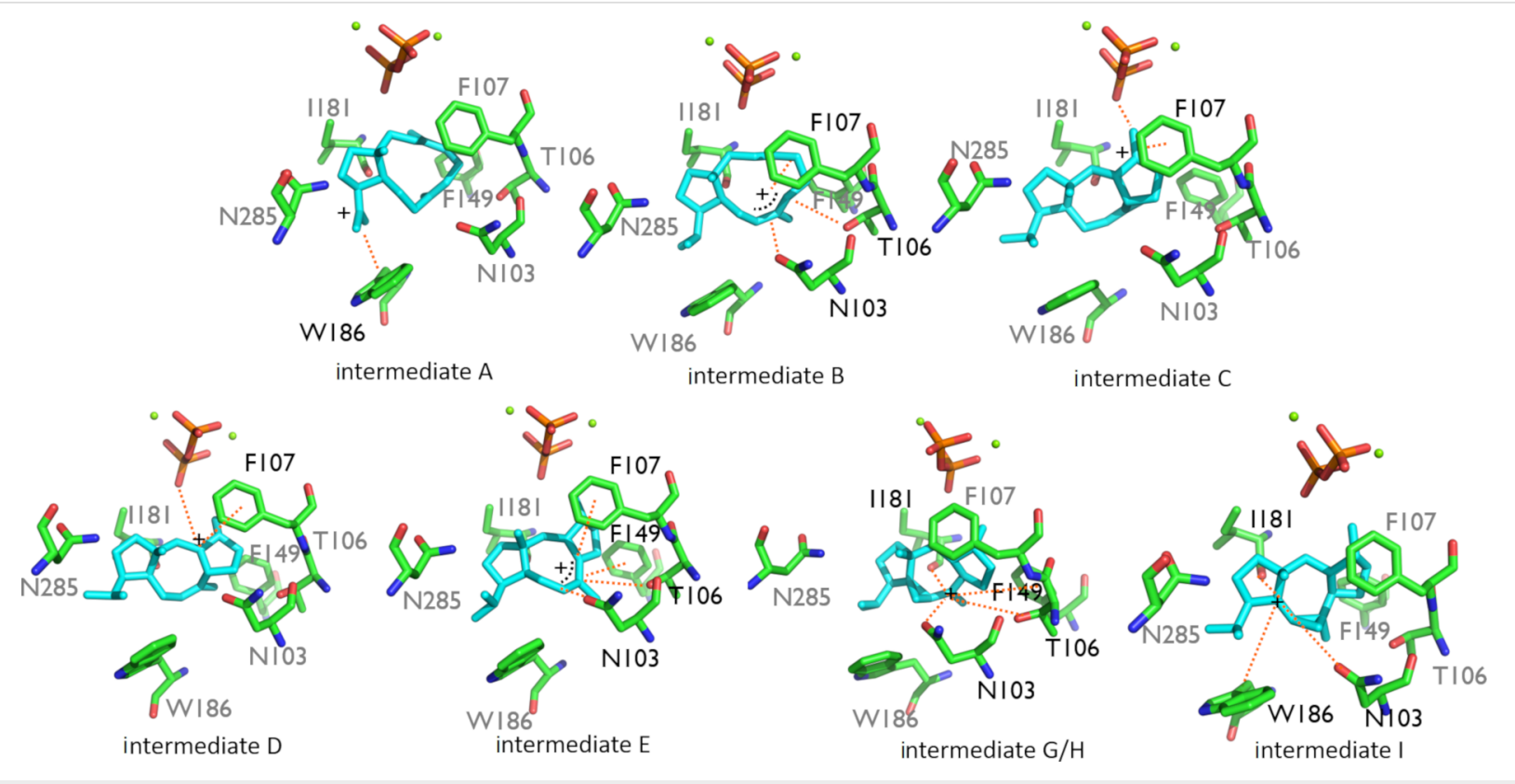

Figure 2: Intermediates A-I in the active site model. Interactions are marked by dashed orange lines, the interacting residues are labeled in black, the non-interacting residues are labeled in grey, and plus signs note location of the cations. 

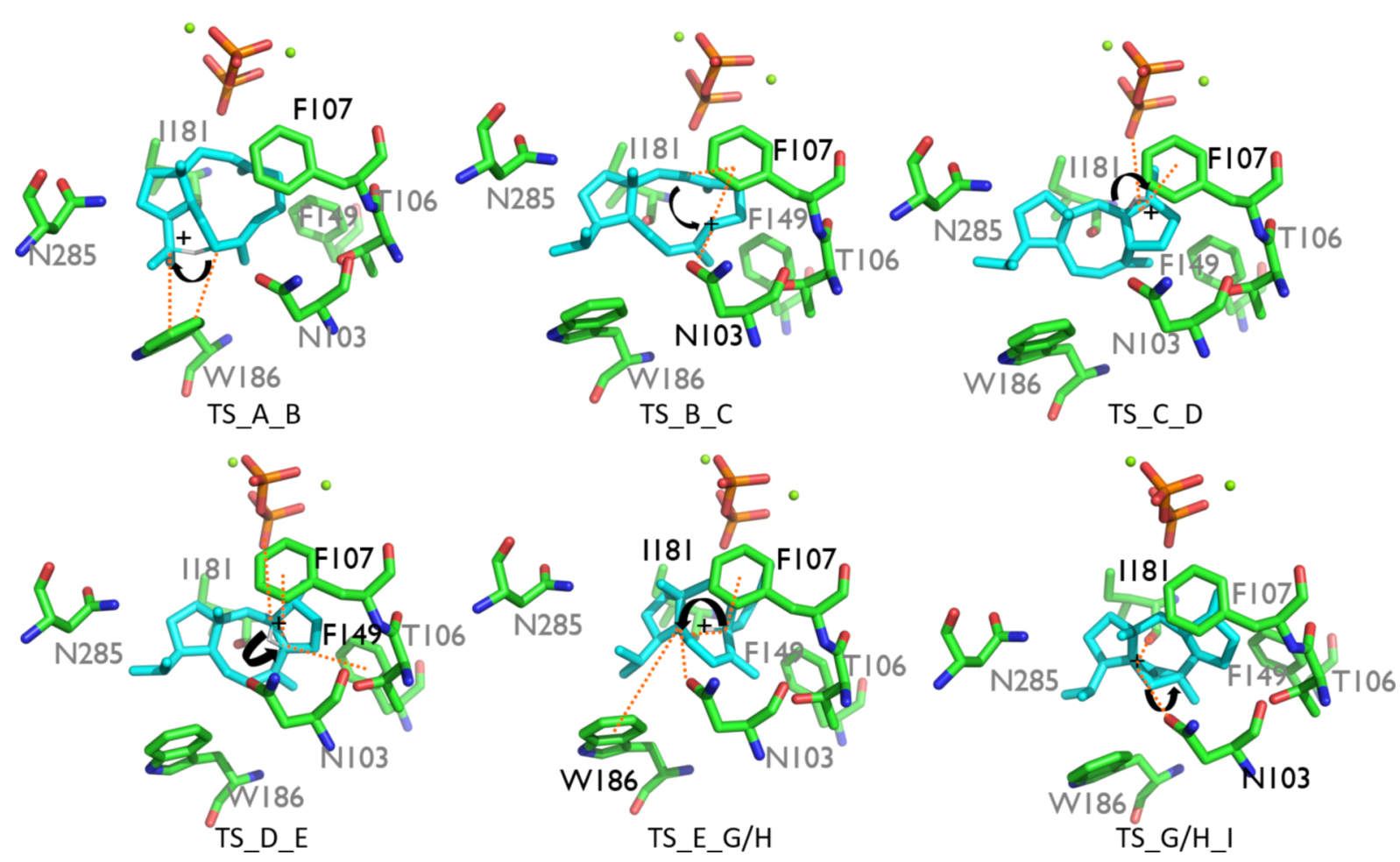

Figure 3: TS structures TS_A_B-TS_G/H_I in the active site model. Interactions are marked by dashed orange lines, the interacting residues are labeled in black, the non-interacting residues are labeled in grey, and the plus signs note the location of the cations.

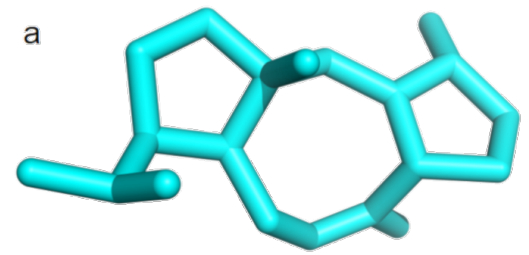

intermediate D - active site model

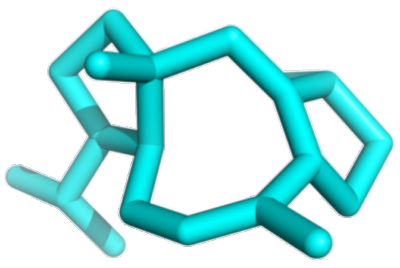

intermediate D - gas phase

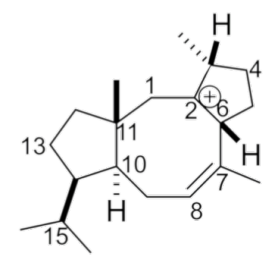

b

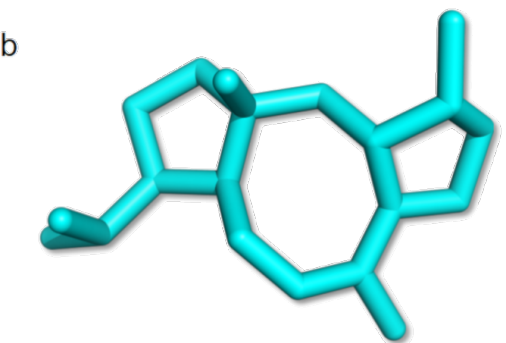

intermediate $\mathrm{E}$ - active site model

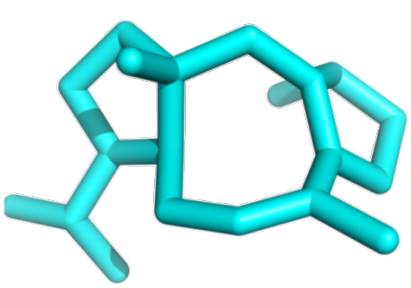

intermediate $\mathrm{E}$ - gas phase

Figure 4: Comparison between gas phase and active site model conformations. A) Intermediate D. B) Intermediate $\mathbf{E}$.

very similar in the gas phase and in the enzyme. Carbocation $\mathbf{H}$ formed interactions with N103, W186, and especially with I181. The relative energy difference between $\mathbf{H}$ and $\mathbf{I}$ was also similar in the gas phase and in the enzyme model. However, the activation energy was higher by $3.0 \mathrm{kcal} / \mathrm{mol}$ in the active site model, possibly due to steric effects. I was stabilized via inter- 
actions with N103, I181, and W186, which likely made similar stabilizing contributions as in cation $\mathbf{H}$.

It is well established that the inherent reactivity of carbocations [27], as well as correct substrate folding in the active site [3] play crucial roles in terpene synthases. The current results highlight the importance of taking into account the active site residues while modeling terpene synthase mechanisms, as we have proposed previously [28-36,42]. We found that the energy surface in the active site model was significantly perturbed compared to the gas phase potential. Additionally, structural analysis revealed that each cation was stabilized by noncovalent interactions, such as $\pi$-cation and dipole-cation interactions. A comparison of the transition state structures in the gas phase vs the active site model is shown in Table 2 . These findings suggest that the rational biosynthesis of novel terpenes might be possible by careful design of CotB2 mutants. Future studies using multiscale techniques to model the enzyme reaction in a complete enzyme environment will allow careful evaluation of the usefulness of such active site theozyme models.

\section{Conclusion}

In this work, we compared the energy profiles of the terpene cyclase CotB2 reaction obtained in the gas phase and using an active site model. The calculations used identical QM methods, facilitating a direct comparison. We presented evidence for the important role played by the active site residues in $\operatorname{CotB} 2$ on the reaction energetics in an active site cluster model, suggesting that reaction control in terpene synthase is obtained via a com- bination of inherent reactivity, initial substrate folding, and enzyme environmental effects. Specifically, the results using the active site model revealed the significant effect that the active site residues have on the relative electronic energy of the intermediates and TS structures in comparison with gas phase data due to ionic, $\pi$-cation, and dipole-cation interactions. A detailed understanding of the role of the enzyme environment on the reaction cascade in $\mathrm{Cot} \mathrm{B} 2$ can provide important information to derive a synthetic strategy for cyclooctatin and related terpene manufacturing. Future studies using hybrid quantum mechanics and molecular mechanics techniques to model the enzyme reaction in a complete enzyme environment will allow careful evaluation of the usefulness of such active site theozyme models.

\section{Experimental}

All calculations were carried out with Gaussian 16 [47]. Geometry optimizations, frequency calculations, and intrinsic coordinate calculations were performed using the M062X/6$31+G(d, p)$ level of theory [48]. The gas phase structures were taken from Sato and co-workers [39]. The amino acid cage was constructed from six amino acids, which were located around the substrate and constituted part of the catalytic pocket of the enzyme (PDB-ID 6GGI) [42]. The chosen amino acids were the ones that we presumed stabilized the carbocations the most during the reaction. The coordinates of the amino acids and the substrate GGPP were taken from the corresponding X-ray structure, with a resolution of $1.8 \AA$ [42]. In this approach, geometry optimizations with the "Modredundant" keyword were per-

\begin{tabular}{|c|c|c|c|c|}
\hline \multirow{2}{*}{$\begin{array}{l}\text { TS structure } \\
\text { TS_A_B }\end{array}$} & \multicolumn{2}{|c|}{ interaction species } & \multirow{2}{*}{$\begin{array}{l}\text { gas phase } \\
\text { distance }(\AA) \\
1.21\end{array}$} & \multirow{2}{*}{$\begin{array}{l}\text { active site model } \\
\text { distance }(\AA) \\
1.29\end{array}$} \\
\hline & $\mathrm{C}_{15}$ & $\mathrm{H}_{82}$ & & \\
\hline & $\mathrm{C}_{8}$ & $\mathrm{H}_{82}$ & 1.46 & 1.34 \\
\hline & $\mathrm{C}_{8}$ & $\mathrm{C}_{15}$ & 2.58 & 2.52 \\
\hline TS_B_C & $\mathrm{C}_{2}$ & $\mathrm{C}_{6}$ & 2.44 & 2.61 \\
\hline \multirow[t]{3}{*}{ TS_C_D } & $\mathrm{C}_{2}$ & $\mathrm{H}_{2}$ & 1.21 & 1.44 \\
\hline & $\mathrm{C}_{3}$ & $\mathrm{H}_{2}$ & 1.48 & 1.24 \\
\hline & $\mathrm{C}_{3}$ & $\mathrm{C}_{2}$ & 1.41 & 1.41 \\
\hline \multirow[t]{3}{*}{ TS_D_E } & $\mathrm{C}_{6}$ & $\mathrm{H}_{6}$ & 1.25 & 1.38 \\
\hline & $\mathrm{C}_{2}$ & $\mathrm{H}_{6}$ & 1.41 & 1.28 \\
\hline & $\mathrm{C}_{2}$ & $\mathrm{C}_{6}$ & 1.41 & 1.42 \\
\hline \multirow[t]{4}{*}{ TS_E_G/H } & $\mathrm{C}_{6}$ & $\mathrm{H}_{6}$ & 1.12 & 1.14 \\
\hline & $\mathrm{C}_{10}$ & $\mathrm{H}_{6}$ & 1.74 & 1.63 \\
\hline & $\mathrm{C}_{10}$ & $\mathrm{C}_{6}$ & 2.63 & 2.49 \\
\hline & $\mathrm{C}_{8}$ & $\mathrm{C}_{10}$ & 2.33 & 2.54 \\
\hline \multirow[t]{3}{*}{ TS_H_I } & $\mathrm{C}_{9}$ & $\mathrm{C}_{7}$ & 1.71 & 1.66 \\
\hline & $\mathrm{C}_{9}$ & $\mathrm{C}_{10}$ & 1.65 & 1.69 \\
\hline & $\mathrm{C}_{10}$ & $\mathrm{C}_{7}$ & 2.48 & 2.46 \\
\hline
\end{tabular}


formed, and the active site residues, diphosphate moiety, and magnesium ions were fixed throughout the reaction progress. The entire cage system was treated using the above-mentioned DFT method. In order to find the TS structures, complete TS optimizations using the keywords "QST2", "QST3", and "Modredundant" were performed.

A main limitation of the current cluster modeling approach was freezing of the active site residues, which did not allow any accommodation of the active site to the evolving reaction intermediates. Flexible residues were not considered due to the possible perturbation of the active site contour and the rapid fluctuation of the total electronic energy as a function of amino acid residue geometry. An additional obvious limitation were medium and long-range nonbonded interactions beyond the active site cage considered here. These effects could be considerable and will be scrutinized in future work.

The Cartesian coordinates of all species are reported in Supporting Information File 1.

\section{Supporting Information}

\section{Supporting Information File 1}

Cartesian coordinates for all species.

[https://www.beilstein-journals.org/bjoc/content/

supplementary/1860-5397-16-7-S1.txt]

\section{Funding}

This work was supported by the Israeli Science Foundation (Grant no. 1683/18).

\section{ORCID ${ }^{\circledR}$ iDs}

Ronja Driller - https://orcid.org/0000-0001-8834-9087 Thomas Brück - https://orcid.org/0000-0002-2113-6957 Bernhard Loll - https://orcid.org/0000-0001-7928-4488 Dan T. Major - https://orcid.org/0000-0002-9231-0676

\section{Preprint}

A non-peer-reviewed version of this article has been previously published as a preprint doi:10.3762/bxiv.2019.108.v1

\section{References}

1. Knowles, J. R. Nature 1991, 350, 121-124. doi:10.1038/350121a0

2. Warshel, A. Proc. Natl. Acad. Sci. U. S. A. 1978, 75, 5250-5254. doi:10.1073/pnas.75.11.5250

3. Christianson, D. W. Chem. Rev. 2017, 117, 11570-11648. doi:10.1021/acs.chemrev.7b00287

4. Devappa, R. K.; Makkar, H. P. S.; Becker, K. J. Am. Oil Chem. Soc. 2011, 88, 301-322. doi:10.1007/s11746-010-1720-9
5. Singh, B.; Sharma, R. A. 3 Biotech 2015, 5, 129-151. doi:10.1007/s13205-014-0220-2

6. Schwab, W.; Davidovich-Rikanati, R.; Lewinsohn, E. Plant J. 2008, 54, 712-732. doi:10.1111/j.1365-313x.2008.03446.x

7. Dewick, P. M. Medicinal Natural Products: A Biosynthetic Approach, 2nd ed.; John Wiley \& Sons: Hoboken, NJ, 2001. doi:10.1002/0470846275

8. Radhakrishna, S.; Kumari, P. S. Adv. Appl. Sci. Res. 2018, 5 (3), 94-101.

9. Rates, S. M. K. Toxicon 2001, 39, 603-613. doi:10.1016/s0041-0101(00)00154-9

10. Gershenzon, J.; Dudareva, N. Nat. Chem. Biol. 2007, 3, 408-414. doi:10.1038/nchembio.2007.5

11. Gonzalez-Burgos, E.; Gomez-Serranillos, M. P. Curr. Med. Chem. 2012, 19, 5319-5341. doi:10.2174/092986712803833335

12. Croteau, R.; Hezari, M.; Hefner, J.; Koepp, A.; Lewis, N. G. Paclitaxel Biosynthesis - The Early Steps. In Taxane Anticancer Agents - Basic Science and Current Status; Georg, G. I.; Chen, T. T.; Ojima, I.; Vyas, D. M., Eds.; ACS Symposium Series, Vol. 583; American Chemical Society: Washington, DC, 1994; pp 72-80. doi:10.1021/bk-1995-0583.ch005

13. Cane, D. E. Chem. Rev. 1990, 90, 1089-1103. doi:10.1021/cr00105a002

14. Christianson, D. W. Chem. Rev. 2006, 106, 3412-3442. doi:10.1021/cr050286w

15. Tholl, D. Curr. Opin. Plant Biol. 2006, 9, 297-304. doi:10.1016/j.pbi.2006.03.014

16. Zwenger, S.; Basu, C. Biotechnol. Mol. Biol. Rev. 2008, 3, 1-7.

17. Janke, R.; Görner, C.; Hirte, M.; Brück, T.; Loll, B. Acta Crystallogr., Sect. D: Biol. Crystallogr. 2014, 70, 1528-1537. doi:10.1107/s1399004714005513

18. Whittington, D. A.; Wise, M. L.; Urbansky, M.; Coates, R. M.; Croteau, R. B.; Christianson, D. W. Proc. Natl. Acad. Sci. U. S. A. 2002, 99, 15375-15380. doi:10.1073/pnas.232591099

19. Lesburg, C. A.; Zhai, G.; Cane, D. E.; Christianson, D. W. Science 1997, 277, 1820-1824. doi:10.1126/science.277.5333.1820

20. Starks, C. M.; Back, K.; Chappell, J.; Noel, J. P. Science 1997, 277 , 1815-1820. doi:10.1126/science.277.5333.1815

21. Wendt, K. U.; Poralla, K.; Schulz, G. E. Science 1997, 277, 1811-1815. doi:10.1126/science.277.5333.1811

22. Köksal, M.; Jin, Y.; Coates, R. M.; Croteau, R.; Christianson, D. W. Nature 2011, 469, 116-120. doi:10.1038/nature09628

23. Croteau, R. Chem. Rev. 1987, 87, 929-954. doi:10.1021/cr00081a004

24. Brück, T.; Kourist, R.; Loll, B. ChemCatChem 2014, 6, 1142-1165. doi:10.1002/cctc.201300733

25. Tantillo, D. J. Nat. Prod. Rep. 2011, 28, 1035-1053. doi:10.1039/c1np00006c

26. Hess, B. A., Jr.; Smentek, L.; Noel, J. P.; O'Maille, P. E. J. Am. Chem. Soc. 2011, 133, 12632-12641. doi:10.1021/ja203342p

27. Tantillo, D. J. Angew. Chem., Int. Ed. 2017, 56, 10040-10045. doi:10.1002/anie.201702363

28. Dixit, M.; Weitman, M.; Gao, J.; Major, D. T. ACS Catal. 2017, 7, 812-818. doi:10.1021/acscatal.6b02584

29. Weitman, M.; Major, D. T. J. Am. Chem. Soc. 2010, 132, 6349-6360. doi:10.1021/ja910134x

30. Major, D. T.; Weitman, M. J. Am. Chem. Soc. 2012, 134, 19454-19462. doi:10.1021/ja308295p

31. Gao, J.; Ma, S.; Major, D. T.; Nam, K.; Pu, J.; Truhlar, D. G. Chem. Rev. 2006, 106, 3188-3209. doi:10.1021/cr050293k 
32. Major, D. T.; Freud, Y.; Weitman, M. Curr. Opin. Chem. Biol. 2014, 21, 25-33. doi:10.1016/j.cbpa.2014.03.010

33. Ansbacher, T.; Freud, Y.; Major, D. T. Biochemistry 2018, 57, 3773-3779. doi:10.1021/acs.biochem.8b00452

34. Dixit, M.; Weitman, M.; Gao, J.; Major, D. T. ACS Catal. 2017, 7, 812-818. doi:10.1021/acscatal.6b02584

35. Freud, Y.; Ansbacher, T.; Major, D. T. ACS Catal. 2017, 7, 7653-7657. doi:10.1021/acscatal.7b02824

36. Major, D. T. ACS Catal. 2017, 7, 5461-5465. doi:10.1021/acscatal.7b01328

37. Newman, D. J.; Cragg, G. M. J. Nat. Prod. 2016, 79, 629-661. doi:10.1021/acs.jnatprod.5b01055

38. Hong, Y. J.; Tantillo, D. J. Org. Biomol. Chem. 2015, 13, 10273-10278. doi:10.1039/c5ob01785h

39. Sato, H.; Teramoto, K.; Masumoto, Y.; Tezuka, N.; Sakai, K.; Ueda, S.; Totsuka, Y.; Shinada, T.; Nishiyama, M.; Wang, C.; Kuzuyama, T.; Uchiyama, M. Sci. Rep. 2015, 5, No. 18471. doi:10.1038/srep18471

40. Kim, S.-Y.; Zhao, P.; Igarashi, M.; Sawa, R.; Tomita, T.; Nishiyama, M.; Kuzuyama, T. Chem. Biol. 2009, 16, 736-743. doi:10.1016/j.chembiol.2009.06.007

41. Meguro, A.; Motoyoshi, Y.; Teramoto, K.; Ueda, S.; Totsuka, Y.; Ando, Y.; Tomita, T.; Kim, S.-Y.; Kimura, T.; Igarashi, M.; Sawa, R.; Shinada, T.; Nishiyama, M.; Kuzuyama, T. Angew. Chem., Int. Ed. 2015, 54, 4353-4356. doi:10.1002/anie.201411923

42. Driller, R.; Janke, S.; Fuchs, M.; Warner, E.; Mhashal, A. R.; Major, D. T.; Christmann, M.; Brück, T.; Loll, B. Nat. Commun. 2018, 9 , No. 3971. doi:10.1038/s41467-018-06325-8

43. Tantillo, D. J.; Jiangang, C.; Houk, K. N. Curr. Opin. Chem. Biol. 1998, 2, 743-750. doi:10.1016/s1367-5931(98)80112-9

44. Siegbahn, P. E. M.; Himo, F. Wiley Interdiscip. Rev.: Comput. Mol. Sci. 2011, 1, 323-336. doi:10.1002/wcms.13

45. Grimme, S.; Steinmetz, M. Phys. Chem. Chem. Phys. 2013, 15, 16031-16042. doi:10.1039/c3cp52293h

46. Mati, I. K.; Cockroft, S. L. Chem. Soc. Rev. 2010, 39, 4195-4205. doi:10.1039/b822665m

47. Gaussian 16, Revision A. 03; Gaussian, Inc.: Wallingford, CT, 2016.

48. Zhao, Y.; Truhlar, D. G. Theor. Chem. Acc. 2008, 120, 215-241. doi:10.1007/s00214-007-0310-x

\section{License and Terms}

This is an Open Access article under the terms of the Creative Commons Attribution License (https://creativecommons.org/licenses/by/4.0). Please note that the reuse, redistribution and reproduction in particular requires that the authors and source are credited.

The license is subject to the Beilstein Journal of Organic Chemistry terms and conditions: (https://www.beilstein-journals.org/bjoc)

The definitive version of this article is the electronic one which can be found at: $\underline{\text { doi:10.3762/bjoc. } 16.7}$ 